\title{
Anti-insulin growth factor receptor therapy in Ewing sarcoma Michael S Isakoff ${ }^{1}$ and Neyssa Marina ${ }^{2 *}$
}

\author{
Addresses: ${ }^{1}$ Division of Hematology-Oncology, Connecticut Children's Medical Center, 282 Washington Street, Hartford, CT 06092, USA; \\ ${ }^{2}$ Division of Hematology-Oncology, Stanford University and Lucile Packard Children's Hospital, Mail Code 5798, 1000 Welch Road, Suite 300, \\ Palo Alto, CA 94304-1812, USA \\ *Corresponding author: Neyssa Marina (nmarina@stanford.edu) \\ Fl000 Medicine Reports 2009, I:62 (doi:10.34I0/MI-62)
}

The electronic version of this article is the complete one and can be found at: http://FI000.com/Reports/Medicine/content/I/62

\begin{abstract}
The insulin-like growth factor (IGF) signal transduction pathway appears to play a key role in the development and proliferation of the Ewing sarcoma family of tumors. Integration of anti-IGF-I receptor therapy into the standard treatment for these patients is a novel approach that will likely be incorporated into future treatment to determine whether such agents will improve the outcome for patients with this malignancy.
\end{abstract}

\section{Introduction and context}

The Ewing sarcoma family of tumors, including Ewing sarcoma and the more differentiated counterpart, primitive neuroectodermal tumor, are the second most common primary malignancies of bone in childhood and adolescence [1] but can also occur in the soft tissues. These tumors are characterized by local destruction with the potential for distant metastatic spread. Treatment is multimodal and includes chemotherapy, surgery, and/or radiation therapy. Systemic chemotherapy is aimed at treating known or micrometastatic disease as well as improving local control of the cancer.

Historically, multiagent chemotherapy has been the standard of care for these patients. The Intergroup Ewing sarcoma study (INT-0091) demonstrated that a regimen of alternating cycles of vincristine-doxorubicincyclophosphamide and ifosfamide-etoposide was superior to vincristine-doxorubicin-cyclophosphamide alone, leading to a 5-year event-free survival of $69 \%$ versus $54 \%$ in the standard arm [2]. More recently, a randomized trial evaluated dose intensification by interval compression (administering cycles every 2 weeks) and found that approach to be superior, with a 4 -year eventfree survival of $76 \%$ in the dose-dense arm compared with $65 \%$ in the standard 3-week chemotherapy arm [3]. This is now considered by pediatric oncologists to be the standard chemotherapy regimen for patients with Ewing sarcoma, although it has not been adequately evaluated in patients older than 18 .

Although there have been improvements in the outcome for patients with localized disease, the outcome for patients with metastatic disease and for those who relapse is poor, with survival rates of $20 \%$ for those with metastases [2,4] and 10-20\% following a recurrence [5]. Therefore, in addition to standard chemotherapeutics, future clinical trials will need to incorporate novel biologic agents in an effort to achieve further survival improvements.

The insulin-like growth factor pathway and cancer The insulin-like growth factor (IGF) system has two principal ligands: IGF-1 and IGF-2. These ligands mediate their stimulatory effects via the IGF-1 receptor (IGF-1R), a transmembrane receptor tyrosine kinase [6]. Under normal physiologic circumstances, IGF-1 and IGF-2 are stimulated by growth hormone and function in a negative feedback loop to control growth hormone release. The insulin growth factor-binding proteins (IGFBPs) regulate the available free IGF proteins available for IGF-1R activation [7-9]. Upon ligand binding, autophosphorylation of the IGF-1R tyrosine kinase initiates activation of the mitogen-activated protein 
kinase and phosphoinositide 3-kinase/AKT pathways, leading to proliferation, survival [10-13], and enhanced angiogenesis via downstream induction of vascular endothelial growth factor [14]. The IGF-2 receptor is a monomeric transmembrane protein with no kinase activity and has not been shown to play a role in the development of Ewing sarcoma [15]. Its role in binding IGF-2 has yet to be elucidated.

The IGF pathway is known to be a critical component of the endocrine system. Stimulation has effects on linear growth and bone formation. The pathway also has a role in promoting neuronal survival, myelination, and postnatal mammary development and lactation. In addition, metabolic pathways use the IGF system to help integrate signals from nutrition and stress in order to shift appropriately between anabolic and catabolic states [6].

High circulating levels of IGF-1 have been associated with the risk of developing prostate, breast, or colorectal cancer $[16,17]$. In addition, overexpression of IGF-1 has been shown to promote neoplastic transformation [18]. The IGF- $1 \mathrm{R}$ is expressed at high levels in a wide variety of tumors $[19,20]$. In addition, IGF-1R expression is known to be necessary for cellular transformation and for signal transduction pathways stimulated by the IGF-1R to enhance tumor cell growth and proliferation [21,22]. Furthermore, IGF-1R gene expression is regulated by a number of tumor suppressors, including WT1, BRCA1, and p53 [20]. There are also data to suggest that signaling through the IGF-1R enhances resistance to cytotoxic chemotherapy [23]. Therefore, inhibition of the IGF-1R is a potentially important therapeutic target against a variety of tumors.

\section{Recent advances}

\section{Targeting insulin-like growth factor I receptor}

\section{in Ewing sarcoma}

The IGF signaling pathway and, in particular, the IGF-1R play a major role in the development and proliferation of Ewing sarcoma. Early studies documented the major autocrine role of the IGF-1 and IGF-1R pathways in Ewing sarcoma [24,25], and expression of IGF-1R has been shown to be a requirement for EWS/FLI-1 transformation in fibroblasts [26]. A variety of approaches in vitro and in animal models have been undertaken to disrupt the IGF-1R signaling pathway, including the development of small-molecule tyrosine kinase inhibitors (TKIs) and anti-IGF-1R antibodies. In preclinical testing, there was an initial difficulty in obtaining specific small-molecule kinase inhibitors of the IGF-1R due to a very-high-sequence homology with kinase and ATP-binding domains of the insulin receptor [27]. Thus, major progress was initially slowed due to toxicity concerns. After initial attempts, the TKI NVPAEW541 was shown to have a 27 -fold increased selectivity for the IGF-1R over the insulin receptor [28]. This small-molecule TKI has shown promise in preclinical models, where inhibition of migration, metastasis, and angiogenesis was seen in vitro and a significant reduction in tumor growth was seen in xenograft models [29]. Further elucidation of the metabolic alterations related to the use of TKIs will be necessary prior to entry into clinical trials.

More recently, targeted antibodies have been shown not only to disrupt ligand-receptor binding, but also to decrease surface IGF-1R expression by internalization and degradation of the antibody-bound receptor $[30,31]$. Human monoclonal anti-IGF-1R antibodies have been produced by many pharmaceutical companies: IMC-A12 (ImClone Systems, New York, NY, USA), AMG 479 (Amgen, Thousand Oaks, CA, USA), R1507 (Roche, Basel, Switzerland), CP-751,871 (Pfizer Inc, New York, NY, USA), SCH717454 (ScheringPlough Corporation, Kenilworth, NJ, USA), MK-0646 (Merck), and AVE1642 (ImmunoGen, Inc, Waltham, MA, USA/Sanofi-Aventis, Paris, France). These antibodies have been tested in preclinical settings and ongoing early-phase adult studies [30,32-36]. However, few of these have been tested in patients with Ewing sarcoma.

The SCH717454 IGF-1R antibody was tested against a panel of pediatric tumors by the Pediatric Preclinical Testing Program, a comprehensive program to systematically evaluate new agents against childhood solid tumor and leukemia models. Intermediate or high activity was demonstrated in two of five Ewing sarcoma xenografts, including one complete response [36]. In addition, the IMC-A12 antibody is currently under investigation in a phase II Children's Oncology Group (COG) trial, with a stratum available for patients with Ewing sarcoma. Through the Sarcoma Alliance for Research through Collaboration (SARC), the R1507 antibody has been tested in two phase I studies in adults $[37,38]$. The first study assessed the administration of the antibody on a 3-week basis and was well tolerated, without any dose-limiting toxicity or serious adverse events; 11 of 26 patients were found to have stable disease, although none had Ewing sarcoma [38]. In the second study, four of eight heavily pretreated patients with Ewing sarcoma demonstrated stable disease, with two of eight patients demonstrating durable partial responses [37]. 


\section{Implications for clinical practice}

Human monoclonal antibody therapy directed against the IGF-1R holds great promise for improving the prognosis for children, adolescents, and adults with Ewing sarcoma. The recent data demonstrating responses in heavily pretreated patients with refractory Ewing sarcoma bring a wave of excitement to move these therapies to the forefront. Clinical trials are under way to assess the feasibility and efficacy of combining antiIGF-1R therapy with multiagent chemotherapy. Over the next 5 years, feasibility testing will be completed, and if successful, phase III studies will assess whether the addition of these new agents will result in therapeutic improvements.

\section{Abbreviations}

BRCA1, breast cancer 1, early onset; COG, Children's Oncology Group; EWS, Ewing sarcoma protein; FLI-1, Friend leukemia integration 1; IGF, insulin-like growth factor; IGFBP, insulin growth factor-binding protein; IGF-1R, insulin-like growth factor 1 receptor; SARC, Sarcoma Alliance for Research through Collaboration; TKI, tyrosine kinase inhibitor; WT1, Wilms tumor 1.

\section{Competing interests}

The authors declare that they have no competing interests.

\section{References}

I. Gurney JG, Davis S, Severson RK, Fang JY, Ross JA, Robison LL: Trends in cancer incidence among children in the U.S. Cancer 1996, 78:532-41.

2. Grier HE, Krailo MD, Tarbell NJ, Link MP, Fryer CJ, Pritchard DJ, Gebhardt MC, Dickman PS, Perlman EJ, Meyers PA, Donaldson SS, Moore S, Rausen AR, Vietti TJ, Miser JS: Addition of ifosfamide and etoposide to standard chemotherapy for Ewing's sarcoma and primitive neuroectodermal tumor of bone. $N$ Engl J Med 2003, 348:694-701.

3. Womer RB, West DC, Krailo MD, Dickman PS, Pawel B: Randomized comparison of every-two-week v. every-three-week chemotherapy in Ewing sarcoma family tumors (ESFT) [abstract]. J Clin Oncol (ASCO Annual Meeting Proceedings) 2008, 26(Suppl 15): 10504.

4. Bernstein ML, Devidas M, Lafreniere $D$, Souid AK, Meyers PA, Gebhardt M, Stine K, Nicholas R, Perlman EJ, Dubowy R, Wainer IW, Dickman PS, Link MP, Goorin A, Grier HE; Pediatric Oncology Group; Children's Cancer Group Phase II Study 9457; Children's Oncology Group: Intensive therapy with growth factor support for patients with Ewing tumor metastatic at diagnosis: Pediatric Oncology Group/Children's Cancer Group Phase II Study 9457-a report from the Children's Oncology Group. J Clin Oncol 2006, 24:152-9.

5. Leavey PJ, Mascarenhas L, Marina N, Chen Z, Krailo M, Miser J, Brown K, Tarbell N, Bernstein ML, Granowetter L, Gebhardt M, Grier HE; Children's Oncology Group: Prognostic factors for patients with Ewing sarcoma (EWS) at first recurrence following multi-modality therapy: a report from the Children's Oncology Group. Pediatr Blood Cancer 2008, 5 I :334-8.

FI000 Factor 6.0 Must Read

Evaluated by Stephen Lessnick II Jun 2008
6. LeRoith $D$, Roberts $C T$ Jr: The insulin-like growth factor system and cancer. Cancer Lett 2003, I95:127-37.

7. Frasca F, Pandini G, Sciacca L, Pezzino V, Squatrito S, Belfiore A, Vigneri R: The role of insulin receptors and IGF-I receptors in cancer and other diseases. Arch Physiol Biochem 2008, I 14:23-37.

8. Hewish M, Chau I, Cunningham D: Insulin-like growth factor I receptor targeted therapeutics: novel compounds and novel treatment strategies for cancer medicine. Recent Pat Anticancer Drug Discov 2009, 4:54-72.

9. Yee D: Targeting insulin-like growth factor pathways. $\mathrm{Br} J$ Cancer 2006, 94:465-8.

10. Giorgetti S, Ballotti R, Kowalski-Chauvel A, Tartare S, Van Obberghen E: The insulin and insulin-like growth factor-I receptor substrate IRS-I associates with and activates phosphatidylinositol 3-kinase in vitro. J Biol Chem 1993, 268:7358-64.

II. Grey A, Chen Q, Xu X, Callon K, Cornish J: Parallel phosphatidylinositol-3 kinase and p42/44 mitogen-activated protein kinase signaling pathways subserve the mitogenic and antiapoptotic actions of insulin-like growth factor I in osteoblastic cells. Endocrinology 2003, I44:4886-93.

12. Hermanto $U$, Zong CS, Wang LH: Inhibition of mitogen-activated protein kinase kinase selectively inhibits cell proliferation in human breast cancer cells displaying enhanced insulin-like growth factor I-mediated mitogen-activated protein kinase activation. Cell Growth Differ 2000, I I:655-64.

13. Petley T, Graff K, Jiang W, Yang H, Florini J: Variation among cell types in the signaling pathways by which IGF-I stimulates specific cellular responses. Horm Metab Res 1999, 31:70-6.

14. Reinmuth N, Liu W, Fan F, Jung YD, Ahmad SA, Stoeltzing O, Bucana CD, Radinsky R, Ellis LM: Blockade of insulin-like growth factor I receptor function inhibits growth and angiogenesis of colon cancer. Clin Cancer Res 2002, 8:3259-69.

I5. van Valen F, Winkelmann W, Jürgens H: Type I and type II insulinlike growth factor receptors and their function in human Ewing's sarcoma cells. J Cancer Res Clin Oncol 1992, I I 8:269-75.

16. Pollak MN, Schernhammer ES, Hankinson SE: Insulin-like growth factors and neoplasia. Nat Rev Cancer 2004, 4:505-18.

17. Renehan AG, Zwahlen M, Minder C, O'Dwyer ST, Shalet SM, Egger M: Insulin-like growth factor (IGF)-I, IGF binding protein-3, and cancer risk: systematic review and meta-regression analysis. Lancet 2004, 363: 1346-53.

18. Kaleko M, Rutter WJ, Miller AD: Overexpression of the human insulinlike growth factor I receptor promotes ligand-dependent neoplastic transformation. Mol Cell Biol 1990, I 0:464-73.

19. Ouban A, Muraca P, Yeatman T, Coppola D: Expression and distribution of insulin-like growth factor-I receptor in human carcinomas. Hum Pathol 2003, 34:803-8.

20. Werner H, Shalita-Chesner M, Abramovitch S, Idelman G, Shaharabani-Gargir L, Glaser T: Regulation of the insulin-like growth factor-I receptor gene by oncogenes and antioncogenes: implications in human cancer. Mol Genet Metab 2000, 71:3I5-20.

21. Baserga R, Sell C, Porcu P, Rubini M: The role of the IGF-I receptor in the growth and transformation of mammalian cells. Cell Prolif 1994, 27:63-7I.

22. Miller BS, Yee D: Type I insulin-like growth factor receptor as a therapeutic target in cancer. Cancer Res 2005, 65:10123-7.

23. Gooch JL, Van Den Berg CL, Yee D: Insulin-like growth factor (IGF)-I rescues breast cancer cells from chemotherapyinduced cell death-proliferative and anti-apoptotic effects. Breast Cancer Res Treat 1999, 56: I- I0.

24. Scotlandi K, Benini S, Sarti M, Serra M, Lollini PL, Maurici D, Picci P, Manara MC, Baldini N: Insulin-like growth factor I receptormediated circuit in Ewing's sarcoma/peripheral neuroectodermal tumor: a possible therapeutic target. Cancer Res 1996, 56:4570-4. 
25. Yee D, Favoni RE, Lebovic GS, Lombana F, Powell DR, Reynolds CP, Rosen N: Insulin-like growth factor I expression by tumors of neuroectodermal origin with the $t(1, ; 22)$ chromosomal translocation. A potential autocrine growth factor. J Clin Invest 1990, 86: |806-|4.

26. Toretsky JA, Kalebic T, Blakesley V, LeRoith D, Helman LJ: The insulin-like growth factor-I receptor is required for EWS/FLI-I transformation of fibroblasts. J Biol Chem 1997, 272:30822-7.

27. Favelyukis S, Till JH, Hubbard SR, Miller WT: Structure and autoregulation of the insulin-like growth factor I receptor kinase. Nat Struct Biol 200I, 8: I058-63.

28. Scotlandi K, Manara MC, Nicoletti G, Lollini PL, Lukas S, Benini S, Croci S, Perdichizzi S, Zambelli D, Serra M, García-Echeverría C, Hofmann F, Picci P: Antitumor activity of the insulin-like growth factor-I receptor kinase inhibitor NVP-AEW54I in musculoskeletal tumors. Cancer Res 2005, 65:3868-76.

29. Manara MC, Landuzzi L, Nanni P, Nicoletti G, Zambelli D, Lollini PL, Nanni C, Hofmann F, García-Echeverría C, Picci P, Scotlandi K: Preclinical in vivo study of new insulin-like growth factor-I receptor-specific inhibitor in Ewing's sarcoma. Clin Cancer Res 2007, I 3: 1322-30.

30. Burtrum D, Zhu Z, Lu D, Anderson DM, Prewett M, Pereira DS, Bassi R, Abdullah R, Hooper AT, Koo H, Jimenez $X$, Johnson D, Apblett R, Kussie P, Bohlen P, Witte L, Hicklin DJ, Ludwig DL: A fully human monoclonal antibody to the insulin-like growth factor I receptor blocks ligand-dependent signaling and inhibits human tumor growth in vivo. Cancer Res 2003, 63:8912-21.

31. Sachdev D, Singh R, Fujita-Yamaguchi Y, Yee D: Down-regulation of insulin receptor by antibodies against the type I insulin-like growth factor receptor: implications for anti-insulin-like growth factor therapy in breast cancer. Cancer Res 2006, 66:2391-402

32. Allen G, Armstrong E, Modhia F, Ludwig DL, Hicklin DJ, Harari P: Inhibition of insulin-like growth factor-I receptor signaling impairs proliferation of head and neck, lung, prostate and breast cancer cells. Proc Amer Assoc Cancer Res 2005, 46:504I.
33. Wang Z, Chakravarty G, Kim S, Yazici YD, Younes MN, Jasser SA, Santillan AA, Bucana CD, El-Naggar AK, Myers JN: Growthinhibitory effects of human anti-insulin-like growth factor-I receptor antibody $(A \mid 2)$ in an orthotopic nude mouse model of anaplastic thyroid carcinoma. Clin Cancer Res 2006, 1 2:4755-65.

34. Wu JD, Odman A, Higgins LM, Haugk K, Vessella R, Ludwig DL, Plymate SR: In vivo effects of the human type I insulinlike growth factor receptor antibody AI2 on androgendependent and androgen-independent xenograft human prostate tumors. Clin Cancer Res 2005, I I:3065-74.

35. Higano CS, Yu EY, Whiting SH, Gordon MS, LoRusso P, Fox F, Katz TL, Roecker JM, Schwartz JD: A phase I, first in man study of weekly IMC-AI2, a fully human insulin like growth factor-I receptor IgGI monoclonal antibody, in patients with advanced solid tumors [abstract]. J Clin Oncol (ASCO Annual Meeting Proceedings) 2007, 25(Suppl 18):3505.

36. Kolb EA, Gorlick R, Houghton PJ, Morton CL, Lock R, Carol H, Reynolds CP, Maris JM, Keir ST, Billups CA, Smith MA: Initial testing (stage I) of a monoclonal antibody ( $\mathrm{SCH} 7$ I 7454) against the IGF-I receptor by the pediatric preclinical testing program. Pediatr Blood Cancer 2008, 50: I 190-7.

37. Leong S, Gore L, Benjamin R, Warren T, Eckhardt SG, Camidge DR, Dias C, Greig G, Frankel S, Kurzrock R: A phase I study of RI 507, a human monoclonal antibody IGF-IR (insulin-like growth factor receptor) antagonist given weekly in patients with advanced solid tumors. Presented at the AACR-NCI-EORTC Molecular Targets and Cancer Therapeutics Meeting: 22-26 October 2007; San Francisco, USA. Abstract 78.

38. Rodon J, Patnaik A, Stein M, Tolcher A, Ng C, Dias C, Greig G, Frankel S, Kurzrock R, Rubin E: A phase I study of q3W RI507, a human monoclonal antibody IGF-IR (insulin-like growth factor receptor) antagonist in patients with advanced solid tumors. Presented at the AACR-NCI-EORTC Molecular Targets and Cancer Therapeutics Meeting: 22-26 October 2007; San Francisco, USA. Abstract 77. 